\title{
Attendance System Application for Lecturers and Students Using RFID and Web Based Raspberry Pi 3+
}

\author{
Agus Triyono ${ }^{1, *}$ Farindika Metandi ${ }^{1}$ \\ ${ }^{1}$ Information Technology, Politeknik Negeri Samarinda, 75131, Indonesia \\ *Corresponding author. Email: triyono@polnes.ac.id
}

\begin{abstract}
Teaching and learning activities often have problems with the absence of lecturers from class in the teaching and learning process even though the lecturers' attendance is recorded. The RFID presence system which has been widely researched does not perform the presence of the two objects, namely lecturers and students. To overcome this, with the aim of the system being able to take notes, it is also a requirement to be able to hold learning activities, both attendance systems are needed at the same time as the previous lecturer did tapping and continued by students. By using the rfid system on the raspberry pi $3+$ as a device and installed in each class in the building, this system can be integrated with the existing network infrastructure without the need to install a new network so that this system can record the presence of lecturers, students and optimal classroom use.
\end{abstract}

Keywords: RFID, Presence System, Raspberry, Python, PHP, Attendance.

\section{INTRODUCTION}

RFID technology is currently experiencing rapid development in its application. In the world of education, one application is its use in the presence information system. Attendance systems can be useful for reducing administration complexity and cost rather than increasing efficiency education $[\mathrm{J}]$. By using this RFID will be able to help academics in recapitulating attendance, disciplining students in terms of arrival on time which will be able to strengthen the goals of Education [1]. Also in its application it can be used to optimize the use of classrooms, so that no room is used simultaneously at one time.

The purpose of this research is that the two applications above can be combined into a system that can track the attendance of lecturers and students with low-cost but reliable resources.

Several studies have been conducted in journals and seminar presentations. They use rfid technology as input I sensor but differ in processing, as has been done by Yulius Beny Kushermanto and Ali Mulyanto et al. using raspberry pi and RC522 modules as student attendance systems [2]. In this study, this system has similarities in the use of a processing device, namely the raspberry pi, but there is no feature for the presence of the teacher. In contrast to what Adnan J. Sadly did, Erdwin Ashari et al. used Arduino Mega as a prototype for the attendance system for teachers and students [3]. The system still creates complexity in terms of devices and programming because it is still a prototype so that it requires further development to add features to the lecturer attendance system and lecture schedule system. The same is done by Nabeel Salih Ali, Ali Al Farawn et al, with the Arduino R3 and the Mifare RC-522 module as RFID Reader and then connected to a computer server via the Arduino Ethernet Shield module. The information system is placed on a separate web-based server computer with TCP / IP[1].

Complementing the above that can be offered in this study is an integrated attendance system using instant modules, easy to operate remotely, with a complete operating system with upgradeable application, and low cost. With the raspberry pi $3+$ and USB RFID Reader and 5 "TFT display, a system with a database, web server, and WiFi TCP / IP connection can be built effectively and efficiently partially in one device. Data is collected in real time to a central server with cluster system to be safe from server damage.

\section{METHOD}

The method used in this research is the waterfall method, because the method is very suitable for both 
development and troubleshoot and also this method is very simple.

It can be seen in Figure 1 that there are 6 processes in conducting research such as:

1. Preliminary Research is the process of collecting various initial information (data) related to the research plan either from the field or the library, which is carried out in order to explore the problem more systematically and intensively as a prelude before carrying out the steps or further research procedures.

2. Design, the approach taken in this design is to use an experimental design approach because it takes deepening for the object to be studied.

3. Hardware and software development, is done by referring to the previous design. In carrying out this stage, it is done by procuring existing hardware and software devices. From this step, customization is carried out for both software and hardware. Whereas in customization is to configure and develop the necessary software programs.

4. Testing: The model that has been built in the previous step can be tested by evaluating the integration of all the subsystems involved, namely carrying out the previous stage again only when needed if the target has not been achieved by the next process.

5. Analysis: In achieving the implementation of the steps previously carried out an analysis must be carried out, whether it is an analysis of the success or not achieving a target to get which process is right to be carried out again.

6. Reporting: In carrying out activities, everything must be recorded in the report, be it success or failure. So that steps can be taken that must be done both in the development step and the evaluation step. In addition, this report can also be used as a useful reference by other parties.

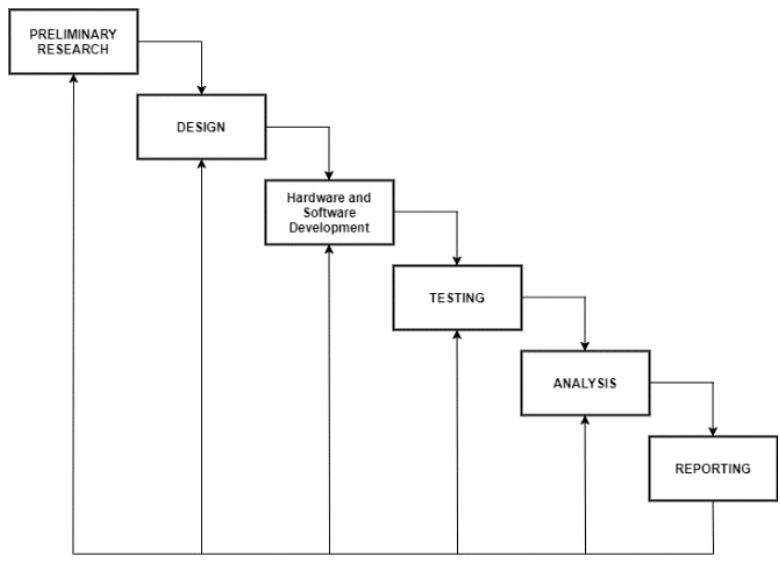

Figure 1 Research Methodology

\section{RESULT AND DISCUSSION}

\subsection{Result}

The application of the attendance system for lecturers and students is able to provide certainty for the teaching and learning process. There are two achievements in building this application, such as:

1. Provide course information in the classroom

2. Provide lecturer attendance information

The following table shows the results of the scheduling system that provides information on the current course schedule. In Table 1 are the results of the scheduling system which is linked through a database for lecturers as course teachers.

Table 1. Course Schedule for Today

\begin{tabular}{|c|l|l|l|l|l|}
\hline id & Lecturer & Subject & Group & Room & Status \\
\hline 1 & Agus Triyono & Sistem Operasi $[\mathrm{P}]$ & TI-1A & Lab.Kom.3 & BELUM DATANG \\
\hline 2 & Tien Rahayu & OoP $[\mathrm{P}]$ & TI-3B & Lab.Kom.2 & BELUM DATANG \\
\hline 3 & Irwansyah & Peng. Citra Digital [P] & TI-4A & Lab.Kom.Vis & BELUM DATANG \\
\hline 4 & Tien Rahayu & Bahasa Inggris I & TK-1A & R.Kelas 6 & BELUM DATANG \\
\hline 5 & MF Andrijasa & Jaringan Komputer & TK-3A & Lab. Jarkom & BELUM DATANG \\
\hline 6 & Irwansyah & Peng. Citra Digital [P] & TK-5A & WS 1 & BELUM DATANG \\
\hline 7 & Karyo Budi Utomo & Pemrograman Dasar [P] & TIM-1A & Lab. Kom.4 & BELUM DATANG \\
\hline 8 & Achmad Rofiq Hakim & Sistem Koordinat dan Tranf Spasial [T] & TIM-3A & R.Kelas 5 & BELUM DATANG \\
\hline 9 & Kasim & Kewarganegaraan & TIM-3B & R.Kelas 1 & BELUM DATANG \\
\hline 10 & Agus Triyono & Kecerdasan Buatan [P] & TIM-5A & WS 2 & BELUM DATANG \\
\hline 11 & Karyo Budi Utomo & Rek. Perangk. Lunak [P] & TI-3D & Lab. Kom.1 & BELUM DATANG \\
\hline 12 & Achmad Rofiq Hakim & Elektronika Lanjut [P] & TK-3D & Lab. Digital & BELUM DATANG \\
\hline 13 & Agus Triyono & Permodelan dan Simulasi & TK-5B & R. Kelas 2 & BELUM DATANG \\
\hline 14 & Tien Rahayu & Bahasa Inggris III & TIM-3C & R. Kelas 4 & BELUM DATANG \\
\hline 15 & Bambang Cahyono & Permodelan dan Simulasi & TIM-5B & R. Kelas 3 & BELUM DATANG \\
\hline 16 & Kasim & Pancasila & TIM-5C & R. Kelas 7 & BELUM DATANG \\
\hline
\end{tabular}


Table 2 can be used as subject for the recapitulation process in academic administration. On Id 61 shows the lecturer has attend to the classroom but at Id 62 and 63 the lectures have been tapped several times, that not affect to the recapitulation process. Without any presence Id 61, 62 and 62, student cannot enter to the class room.

Table 2. List Of Attendance Lecturer and Student

\begin{tabular}{llllll} 
Id & Rfid & Subject & Lecturer & Room & Time \\
\hline 61 & 1517955191 & Sistem Operasi [P] & Agus Triyono & Lab Kom 3 & 2020-08-23 09:51:36 \\
\hline 62 & 1517955191 & Sistem Operasi [P] & Agus Triyono & Lab Kom 3 & 2020-08-23 10:25:45 \\
\hline 63 & 1517955191 & Sistem Operasi [P] & Agus Triyono & Lab Kom 3 & 2020-08-23 10:29:28 \\
\hline 64 & 3026091063 & Sistem Operasi [P] & Agus Triyono & Lab Kom 3 & 2020-08-23 10:29:28 \\
\hline 65 & 3026091063 & Sistem Operasi [P] & Agus Triyono & Lab Kom 3 & 2020-08-23 10:25:45 \\
\hline 66 & 3024835639 & Sistem Operasi [P] & Agus Triyono & Lab Kom 3 & 2020-08-23 10:25:45 \\
\hline 67 & 3024835639 & Sistem Operasi [P] & Agus Triyono & Lab Kom 3 & 2020-08-23 10:29:28 \\
\hline
\end{tabular}

On the TFT LCD screen at Figure 2, is the name of the course along with the information on the attendance of the lecturer is not existence yet in the classroom.

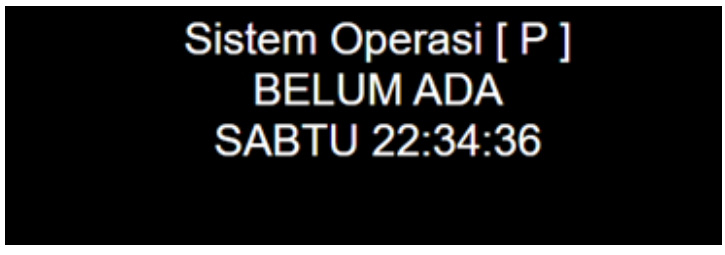

Figure 2 Lecturer Attendance Status Not Present

On Figure 3, shows that the lecturer is present, and teaching and learning can be beginning.

This simple display is very useful for students about the certainty of lecturers' arrival, it can also provide information in raw for academic's department.

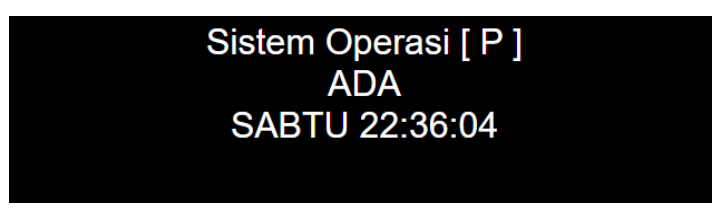

Figure 3 Lecture Attendance Status Is Present

\subsection{Discussion}

\subsubsection{Raspberry Pi}

The Raspberry Pi is an SBC (Single-Board Computer) about the size of a credit card. Raspberry pi is equipped with all the functions of a complete computer, using the ARM SOC (System-on-a-Chip) which is packaged and integrated on the PCB (circuit board). The Raspberry $\mathrm{Pi}$ is able to work like a computer in general with the ability to run the Linux operating system and applications such as LibreOffice, multimedia (audio and video), web browsers, or programming [4]. Figure 4 shows the board of Raspberry Pi and figure 5 shows TFT LCD Touch Screen for Raspberry.

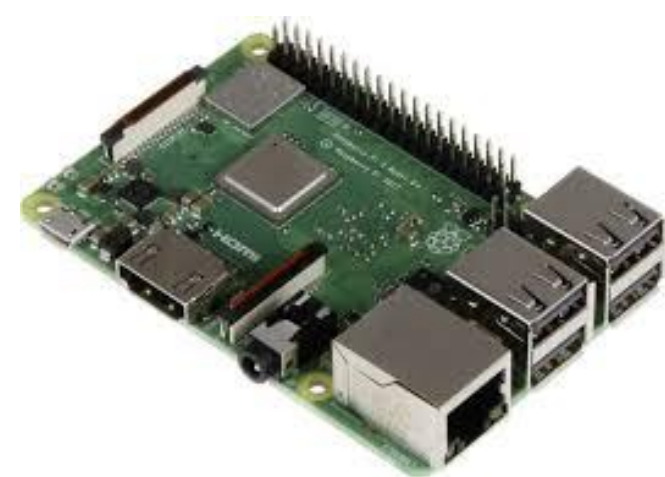

Figure 4 Board of Raspberry $\mathrm{Pi}[5]$

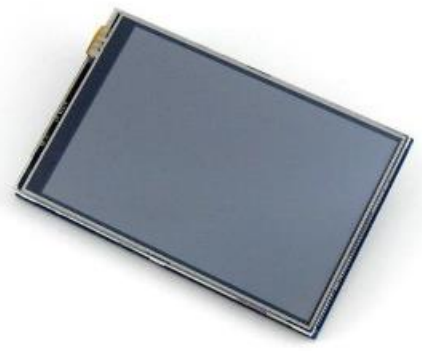

Figure 5 TFT LCD Touch Screen for Raspberry[6]

The small screen, which is the same size as the Raspberry $\mathrm{Pi}$, is a 3.5 " resistive touch screen with a resolution of $480 \times 320$. On the PCB LCD there are 40 pins (female) that are plugged into a single Raspberry board as an interface.

\subsubsection{RFID Tag and Reader}

RFID tag is a card-shaped device that stores information for object identification, RFID tags only contain unique ID tags that are different from one another. RFID tags are divided into two, namely active tags and passive tags. Active tags are tags whose power supply is obtained from the battery, so that it will reduce the power obtained by the RFID reader and tags can transmit information over a longer distance. Whereas 
passive tags are tags whose power supply is obtained from the field generated by the RFID reader [7].

RFID reader is an RFID tag reader that communicates with the tag card wirelessly. There are two kinds of RFID readers, namely passive readers and active readers. Passive RFID has a passive reader system that only receives radio signals from active tagged RFID, while active readers have a reader system that thinks of the interrogator signal to the tag and receives an authentication reply from the tag. This interrogator signal also induces the tag and ultimately becomes a DC signal which becomes a passive tag resource [7].

There are several modes of RFID reading on the raspberry, namely reading via SPI, I2C. UART or USB. Separate interfacing and configuration are required when using SPI, I2C and UART, but USB can be used instantly[8]. Figure 6 shows USB RFID Reader.

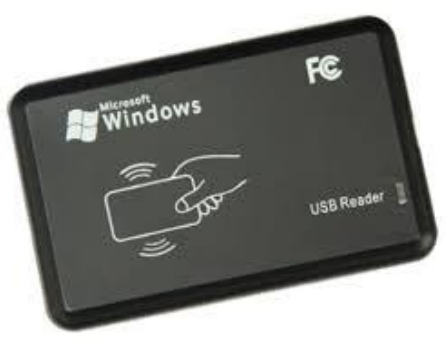

Figure 6 USB RFID Reader[9]

\subsubsection{MariaDB Database Engine}

MariaDB is a database server that is used to store and manage data. MariaDB is not much different from MySQL, because MariaDB is an open and independent development version of MySQL. Since the acquisition of MySQL by Oracle in September 2010, Monty Program as the original author of the MySQL source code has separated itself from development and created a more independent version, MariaDB. Until now, many have migrated from MySQL to MariaDB, for example, the giant Google company and also large sites like Wikipedia. One of the advantages of MariaDB is that it has pretty good performance and is not heavy and is compatible with MySQL [10].

MariaDB is also compatible with various database server that is used to store and manage data. MariaDB is not much different from MySQL, because MariaDB is an open and independent development version of MySQL. Since the acquisition of MySQL by Oracle in September 2010, Monty Program as the original author of the MySQL source code has separated itself from development and created a more independent version,
MariaDB. Until now, many have migrated from MySQL to MariaDB, for example, the giant Google company and also large sites like Wikipedia. One of the advantages of MariaDB is that it has pretty good performance and is not heavy and is compatible with MySQL. MariaDB is also compatible with various platforms such as LINUX, Windows, MacOS, FreeBSD, Solaris [11].

\subsubsection{Python}

Python is an open-source programming language. This programming language is optimized for software quality, developer productivity, portability programs, and component integration. Python has been used to develop various kinds of software, such as internet scripting, programming systems, user interfaces, product customization, numberic programming, etc. Python is currently in the 4 th or 5 th position of the most used programming languages in the world [12].

\subsubsection{PHP}

PHP is a web-based programming language where the system implemented is on the server side. PHP can be inserted between HTML language scripts and other server side language arenas, with that PHP will be executed directly on the server [13][14].

\subsubsection{Apache}

The web server application is software that runs on the server side and is tasked with receiving requests from a web browser, translating the request, and returning to the web browser the results of the request[15]. It is known as "Apache HTTP Server" which allows distribution of website services online using the Hyper Text Transfer Protocol (HTTP). This Web Server is very popular for different operating systems such as Linux, Unix, Windows, Solaris, Mac OS X, Novell NetWare, OS / 2, etc.[16].

\subsubsection{Context Diagram Design}

In Figure 7, the DFD 0 design appears to make it easier to maintain the flow in programming and configuration implementation. Detailed implementation related to the system can be seen in the flowchart.

\subsubsection{Entity Relationship Database Design (ERD)}

Figure 8 shows the correlation between the tables. This is necessary to determine the required table structure. 


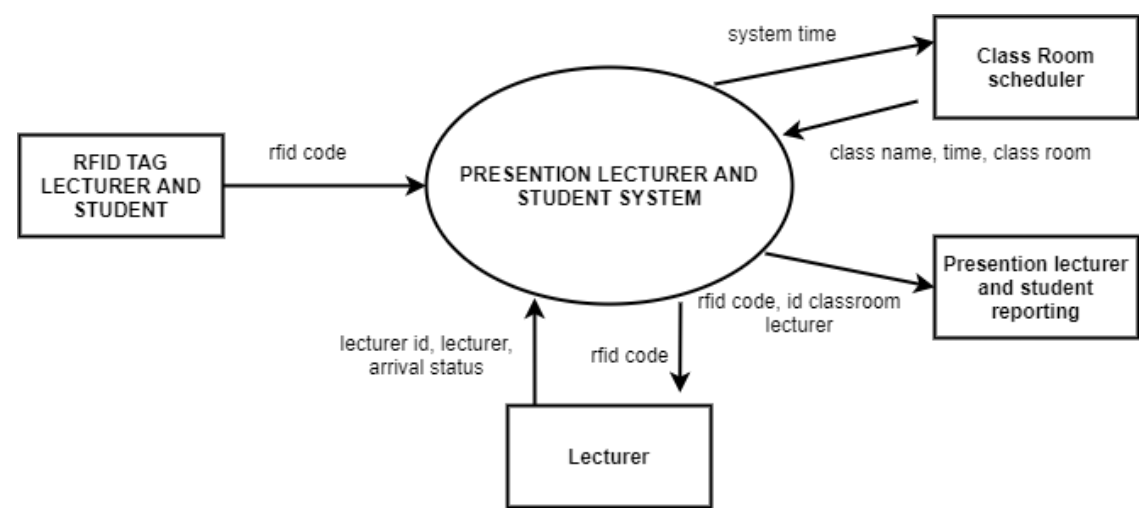

Figure 7 Context Diagram (DFD 0)

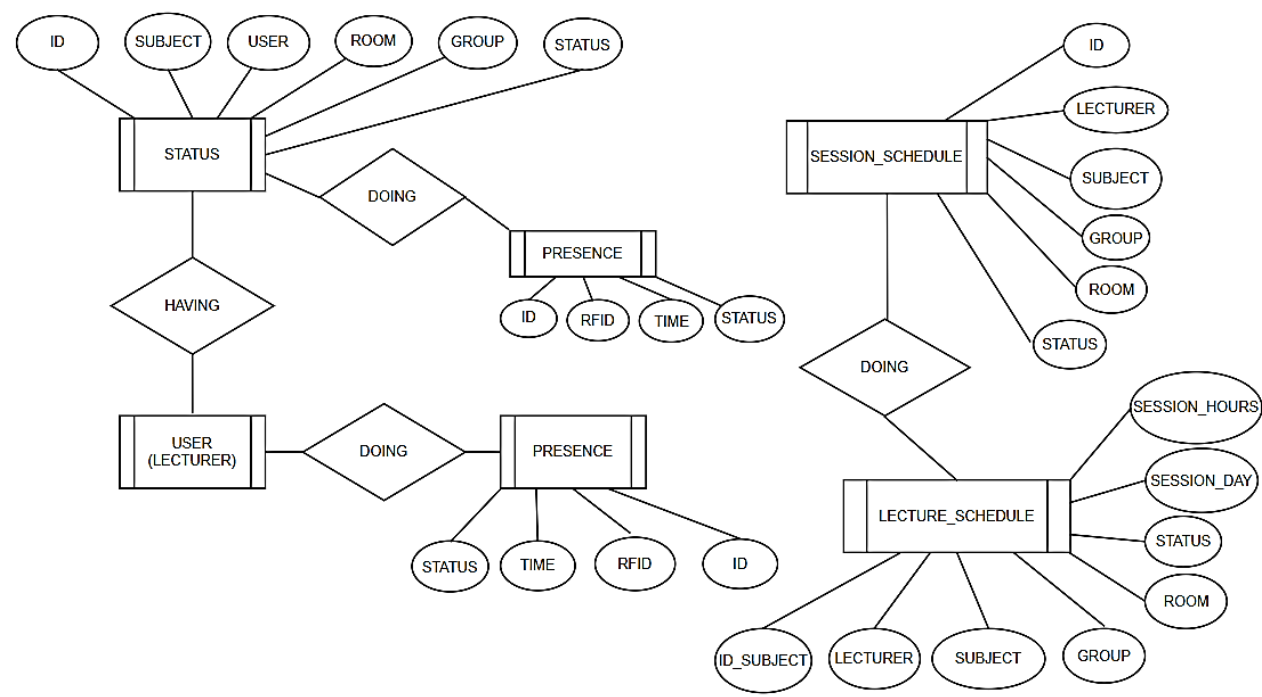

Figure 8 Entity Relationship Database (ERD) Design

\subsubsection{Table Structure}

Figure 9 stores all lecture schedule information for one semester and hours and its lecturer, this table is static unless there is a change in class schedule.

\begin{tabular}{|c|c|c|c|c|}
\hline & $\#$ & Name & Type & Collation \\
\hline$\square$ & 1 & Id_Subject & $\operatorname{int}(8)$ & \\
\hline$\square$ & 2 & Lecturer & varchar(20) & utf8mb4_general_ci \\
\hline & 3 & Subject & varchar(50) & utf8mb4_general_ci \\
\hline & 4 & Class_Group & varchar(20) & utf8mb4_general_ci \\
\hline & 5 & Room & varchar(20) & utf8mb4_general_ci \\
\hline$\square$ & 6 & Status & varchar(20) & utf8mb4_general_ci \\
\hline$\square$ & 7 & Note & varchar(40) & utf8mb4_general_ci \\
\hline$\square$ & 8 & Session_Day & varchar(10) & utf8mb4_general_ci \\
\hline$\square$ & 9 & Session_Hour & time & \\
\hline
\end{tabular}

Figure 9 Lecture Schedule Table
Figure 10 shows the table stores the lecture schedule information taken from the lecture schedule table, through a script that contains a computer system time comparison and the time on the schedule.

\begin{tabular}{|c|c|c|c|}
\hline$\#$ & Name & Type & Collation \\
\hline 1 & id & int(100) & \\
\hline 2 & Lecturer & varchar(20) & utf8mb4_general_ci \\
\hline 3 & Subject & varchar(50) & utf8mb4_general_ci \\
\hline 4 & Class_Group & varchar(20) & utf8mb4_general_ci \\
\hline 5 & Room & varchar(20) & utf8mb4_general_ci \\
\hline 6 & Status & varchar(20) & utf8mb4_general_ci \\
\hline
\end{tabular}

Figure 10 Lecture Schedule Session Table

Figure 11 is designed for logging system. This table will contain information on logging data that was successfully tapped but not validated to enter the classroom. 


$\begin{array}{lllll}\text { \# } & \text { Name } & \text { Type } & \text { Collation } \\ \square & 1 & \text { id } & \text { int(10) } & \\ \square & 2 & \text { Rfid } & \text { varchar(20) utf8mb4_general_ci } \\ \square & 3 & \text { Time date } & \\ \square & 4 & \text { Status varchar(10) utf8mb4_general_ci }\end{array}$

Figure 11 Logging Table

Figure 12 Contains verified lecturer information on both the schedule and the attendance of the lecturer in the room, this table is used to recapitulate the attendance of lecturers and students.

$\begin{array}{lllll} & \text { \# } & \text { Name } & \text { Type } & \text { Collation } \\ \square & 1 & \text { id } & \text { int(10) } & \\ \square & 2 & \text { Rfid } & \operatorname{varchar}(20) & \text { utf8mb4_general_ci } \\ \square & 3 & \text { Time date } & \\ \square & 4 & \text { Status varchar(10) utf8mb4_general_ci }\end{array}$

\section{Figure 12 Presence Table}

Figure 13 Contains information on the presence of lecturers via tapped RFID. The status table is static, which is filtered from the schedule of the staff distributed by the department.

$\begin{array}{lllll}\text { \# } & \text { Name } & \text { Type } & \text { Collation } \\ \square & 1 & \text { id } & \text { int(10) } & \\ \square & 2 & \text { Subject } & \operatorname{varchar}(20) & \text { utf8mb4_general_ci } \\ \square & 3 & \text { User } & \text { varchar(20) utf8mb4_general_ci } \\ \square & 4 & \text { Room } & \text { varchar(20) utf8mb4_general__ U } \\ \square & 5 & \text { Class_Group } & \operatorname{varchar}(50) & \text { utf8mb4_general_ci } \\ \square & 6 & \text { Status } & \operatorname{varchar}(20) & \text { utf8mb4_general_ci }\end{array}$

Figure 13 Status Table

Table in Figure 14 is Used to verify whether a lecturer is recorded as having RFID.

$\begin{array}{lllll}\text { \# } & \text { Name } & \text { Type } & \text { Collation } \\ \square & 1 & \text { id } & \text { int(10) } & \\ \square & 2 & \text { User_Name } & \operatorname{varchar}(20) & \text { utf8mb4_general_ci } \\ \square & 3 & \text { Subject } & \operatorname{varchar}(20) & \text { utf8mb4_general_ci } \\ \square & 4 & \text { RFID_No } & \operatorname{varchar}(20) & \text { utf8mb4_general_ci } \\ \square & 5 & \text { Status } & \text { varchar(10) } & \text { utf8mb4_general_ci }\end{array}$

Figure 14 User Table

\subsubsection{Flow Chart}

In Figure 15 shows lecture schedule is checked every 1 minute through the linux scheduling system, namely cron tab. In the crontab, execute a script containing lecture time schedules. Cron tab executes a script that filters the schedule_kuliah table and is inserted into the schedule_session table. The schedule_session table will change every minute when the computer system time and the time in the lecture_schedule table are the same.

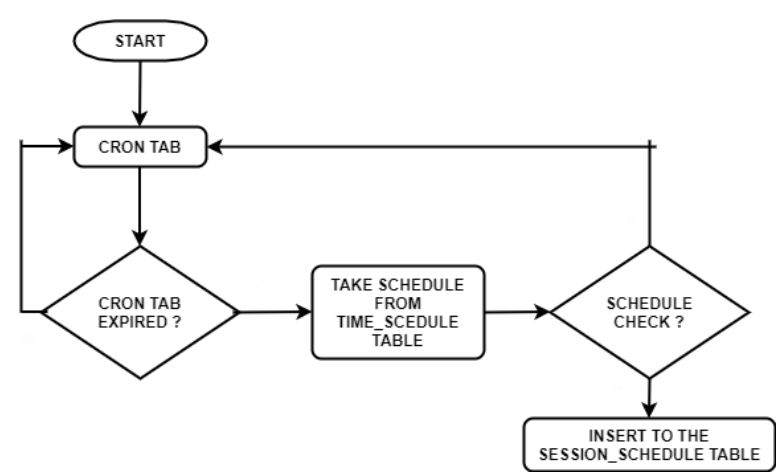

Figure 15 Time Schedule Timer

Figure 16, the attendance schedule starts from the RFID tap card. Anyone tapping will be recorded in the log table, namely the attendance table.

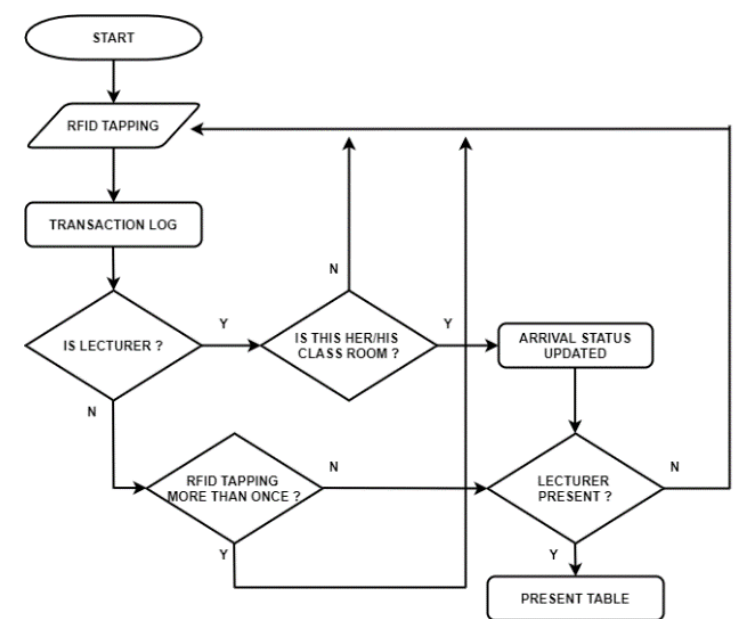

Figure 16 Presence Flow Chart

This table contains both transactions that are verified as user or not. Then the system will verify whether the appropriate. If the verification results are YES, the status table will be updated to PRESENT, which before by

\subsubsection{Testing}

In the figure 17 , the testing mechanism is shown by bringing the rfid card closer to the USB RFID reader. The result of the card number reading is displayed on the console to confirm that the card has been read by using python script and can be seen on Figure 18. 


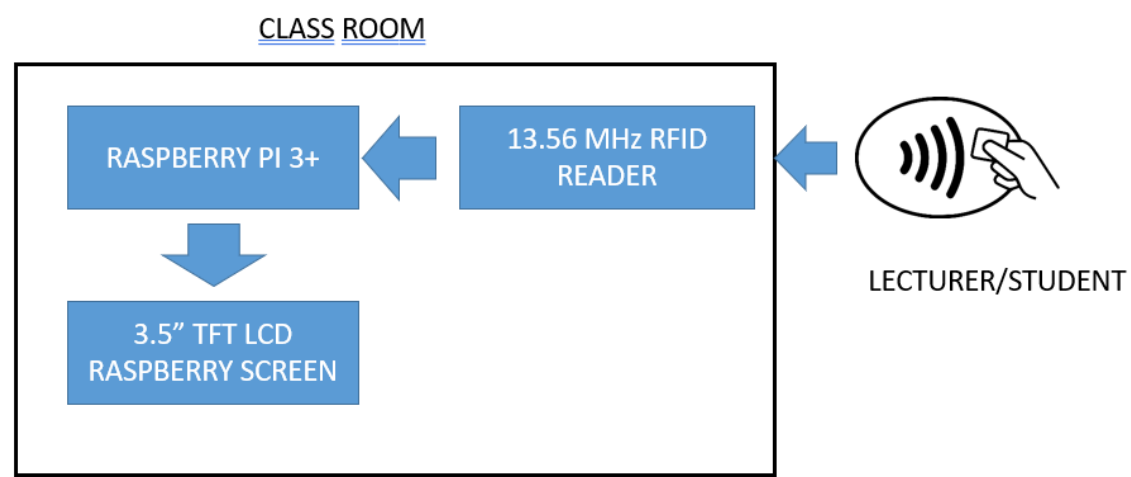

Figure 17 Block Diagram

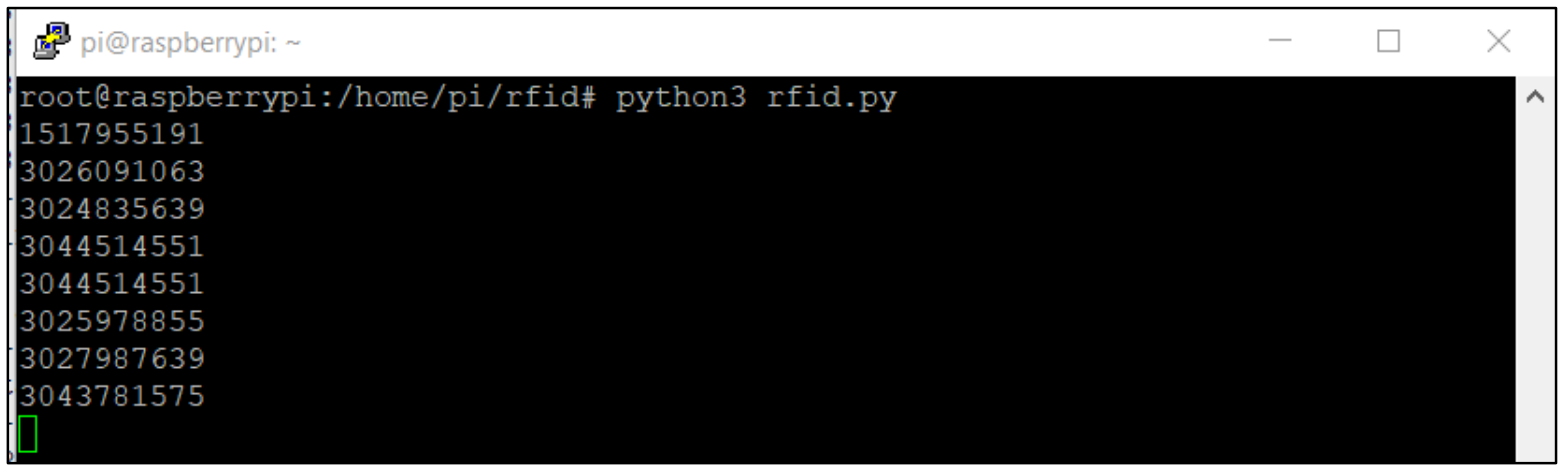

Figure 18 Tapping Console

\section{CONCLUSION}

The attendance system for lecturers and students can be implemented to manage room information, track the attendance of lecturers and students, assess students for discipline in attendance, provide lecture schedule information which is all done integrated and reliable manner. By using Raspberry Pi $3+$ as the embedded system, the system works very well, especially in terms of the presence of lecturers and students, scheduling courses, and the room usage. The system can be used for online academic purposes by using the existing network infrastructure, so that data can be accessed very quickly and precisely. The system can be expanded by duplicating one device, either hardware or software. Also this system can be developed with various features including access control, display with signate-board, automatic payment, attendance statistics for lecturers and students, and others.

\section{ACKNOWLEDGMENTS}

Really had a deep impression in doing this research. Gratitude to Politeknik Negeri Samarinda so that this research was carried out and the simlitabmas which provided an opportunity to provide funding so that the research could be completed.

\section{REFERENCES}

[1] H. D. Rjeib, N. S. Ali, A. Al Farawn, B. Al-Sadawi, and H. Alsharqi, "Attendance and information system using RFID and web-based application for academic sector," Int. J. Adv. Comput. Sci. Appl., vol. 9, no. 1, pp. 266-274, 2018, doi: 10.14569/IJACSA.2018.090137.

[2] Y. B. Kushermanto and A. Mulyanto, "Penerapan Teknologi RFID Modul RC522 Berbasis Raspberry Pi B + Pada Sistem Absensi Siswa di SMK AtTaqwa Cabangbungin Kabupaten Bekasi," J. Inform. SIMANTIK, vol. 1, no. 2, pp. 26-31, 2017.

[3] D. A. N. Mahasiswa, "Jurnal It Prototype Sistem Absensi Tenaga Pengajar,” vol. 9, no. 2, pp. 148$157,2018$.

[4] L. Affandi1, Ekojono, and Ahmad Rizaldi, "Sistem Presensi Menggunakan Nfc Smartphone Android Dan Raspberry Pi (Studi Kasus Politeknik Negeri Malang)," J. Inform. Polinema, vol. 6, no. 3, pp. 7582, 2020, doi: 10.33795/jip.v6i3.299.

[5] Amazon.co.uk, "Raspberry Pi 3 Model B Quad Core CPU 1.2 GHz 1 GB RAM Motherboard," 2020. https://www.amazon.co.uk/Raspberry-Pi-Model- 
Quad-Motherboard/dp/B01CD5VC92 (accessed Nov. 27, 2020).

[6] S. Raspian, "3.5 inches TFT Touchscreen for Raspberry Pi SKU: DFR0428.”

[7] A. Z. Hasibuan, H. Harahap, and Z. Sarumaha, "Penerapan Teknologi RFID Untuk Pengendalian Ruang Kelas Berbasis Mikrokontroler," J. Teknol. dan Ilmu Komput. Prima, vol. 1, no. 1, pp. 71-77, 2018, doi: 10.34012/jutikomp.v1i1.326.

[8] J. Mankar, C. Darode, K. Trivedi, M. Kanoje, and P. Shahare, "Review of I2C Protocol," Int. J. Res. Advent Technol., vol. 2, no. 1, pp. 2321-9637, 2014.

[9] makerlab-electronics, "13.56Mhz USB RFID Card Reader," 2020. https://www.makerlabelectronics.com/product/13-56mhz-usb-rfid-cardreader/ (accessed Nov. 27, 2020).

[10] H. Bouzaida, "Conceptualization and Realization of a Database Migration Path for an Interna- tional and mHealth Tinnitus Database," 2019.

[11] I. Warman and R. Ramdaniansyah, "Analisis Perbandingan kinerja Query Database Management System (Dbms) Antara Mysql 5.7.16 dan Mariadb 10.1," J. Teknoif, vol. 6, no. 1, pp. 32-41, 2018, doi: 10.21063/jtif.2018.v6.1.32-41.
[12] A. F. Harismawan, A. P. Kharisma, and T. Afirianto, "Analisis Perbandingan Performa Web Service Menggunakan Bahasa Pemrograman Python, PHP, dan Perl pada Client Berbasis Android," J. Pengemb. Teknol. Inf. dan Ilmu Komput. e-ISSN, vol. 2548, p. 964X, 2018.

[13] K. M. S. Haryana, "Pengembangan Perangkat Lunak dengan Menggunakan PHP," J. Comput. Bisnis, vol. 2, no. 1, pp. 14-21, 2015.

[14] H. Bogunovic, E. Pek, S. Loncaric, and V. Mornar, "An electronic journal management system," in Proceedings of the 25th International Conference on Information Technology Interfaces, 2003. ITI 2003., 2003, pp. 231-236, doi: 10.1109/ITI.2003.1225350.

[15] R. Dawood, S. F. Qiana, and S. Muchallil, "Kelayakan Raspberry Pi sebagai Web Server: Perbandingan Kinerja Nginx, Apache, dan Lighttpd pada Platform Raspberry Pi," J. Rekayasa Elektr., vol. 11, no. 1, pp. 25-29, 2014, doi: 10.17529/jre.v11i1.1992.

[16] G. Birajdar, "Implementation of Embedded Web Server Based on ARM11 and Linux using Raspberry PI," Int. J. Recent Technol. Eng., no. 3, pp. 2277-3878, 2014. 